Article

\title{
Vegetation Conditions in Sacred Compounds at Myanmar's Bagan Cultural Heritage Site
}

\author{
Min Zar Ni Aung *,t这 and Shozo Shibata ${ }^{\dagger}$ \\ Laboratory of Landscape Architecture, Division of Forest and Biomaterials Science, Graduate School of \\ Agriculture, Kyoto University, Kyoto 606-8502, Japan; sho@kais.kyoto-u.ac.jp \\ * Correspondence: minzarniaung@gmail.com \\ † These authors contributed equally to this work.
}

Received: 21 September 2019; Accepted: 25 October 2019; Published: 28 October 2019

check for updates

\begin{abstract}
Scrub vegetation encroaches into the proximity of many monuments at Myanmar's Bagan Cultural Heritage Site, as can be seen at many other monuments on the world. The extensiveness of scrub vegetation can interfere with the integrity of the cultural landscape when ignored by site management. The current study examined how significant the occurrence of scrub vegetation might be, quantifying the canopy coverage with relative occupancy of other components in the sacred compounds. The sacred compounds in Bagan enclose religious monuments in environments classified as farmland, monastic residences, accessways, shrub-hosting areas, and scrub vegetation. The coverage of scrub vegetation was more than a quarter of the area of sacred compounds, whereas that of shrub-hosting patches was about half. The other components occupied less than one-fifth of the area. The associated occurrence of scrub vegetation indicated the invasion of alien species from the drier hinterland to the riverside of Ayeyarwady. While such a situation reveals site management as a priority, the presence of cultivated farmland in the vicinity of monuments represented suppression of weedy growth that may later facilitate the occurrence of scrub-type plants. This study suggests cultivation as a reasonable practice for the integrity of the cultural landscape and safeguarding the monuments in Bagan.
\end{abstract}

Keywords: Bagan; Myanmar; monument; sacred compound; cultural heritage; scrub vegetation; farmland

\section{Introduction}

Vegetation encroachment on monuments is a noticeable condition in many archaeological sites that reflects issues of site management across the globe [1,2]. The colonized patch of vegetation on the monuments and the site generally comprises a diversity of higher plants, which, in turn, may be associated with the incidence of moss, lichen, and fungi [2-4]. Despite the importance of biodiversity in such a context, vegetation encroachment on the monuments is a root-cause for deterioration of the architectural structures $[5,6]$. Root penetration of woody vegetation into the monuments induces cracks in the structures, degrading structural integrity [1,3]. Such conditions are quite common for monuments at abandoned archaeological sites, where preservation in connection with site management is a requirement $[2,7]$.

At the Bagan Cultural Heritage Site in Myanmar, woody vegetation covers 37\% of Monumental Zone 1 (MZ-1) [8] (see Figure 1b). Existing in the dry zone of Myanmar, the woody vegetation in Bagan is presumablymostly scrub-type plants. As is often seen in semi-arid ecological conditions, stands of Acacia and Zizyphus species are typical across the dry zone [9,10]. These common species, both in shrub and tree forms, share a habitat with the fleshy and thorny Euphorbia antiquorum and the shrub-like Osyris wightiana in the drier parts of Myanmar [11]. According to the Food and Agricultural 
Organization (FAO) [10], Acacia leucophloea, Acacia catechu, Zizyphus jujuba, and Azadirachta indica are native to the dry zone of Myanmar, while Prosopis juliflora is known to be exotic.

The occurrence of vegetation in an archaeological site also relates to past anthropogenic activities of land utilization and plant introductions [12,13]. The past settlements and agricultural activities have altered the landscape characteristics, including the succession of vegetation over time at a given site $[14,15]$. In the Bagan area of Myanmar, archaeological surveys documented that residential sites were dotted around the Old City dating back from the 13th to 7th centuries A.D. [16,17]. During the zenith of Bagan (11th-13th centuries A.D.), constructions of various-sized religious buildings erected typical solid-core stupa (a mound-like or hemispherical structure containing relics with pyramidal or bulbous shapes), temples, and monasteries $[18,19]$. Dedicated to the school of Buddhism, donors of the religious buildings also offered acres of arable land to provide in-kind payment for maintenance of the architectural structures and food for monks [20]. Since then, several hectares of cultivated land had developed nearby temples and monasteries in Bagan [21]. Most of the glebe lands were loyalties to the monks, who represented the authoritative religious body in Myanmar's history [22]. The land in Bagan appeared to be under extensive coverage of main crops including sesamum, millet, and sorghum since the dry-land ecosystem had favored these crops [23,24]. Sesamum was extensively grown for cooking oil and lighting, while the other two crops were for grain during the Bagan Era [23]. Despite a lack of information on how progressive human interventions as the cultural trend had altered the overall landscape of the Bagan plain, a massive proportion of the cultural heritage site can generally be seen today as level terrain with plenty of agricultural fields on sandy-loam soil and scrub vegetation, monuments of various sizes super-imposed on them.

Many of the religious monuments in Bagan are in enclosures (henceforth referred to as sacred compounds), which were dedicated by sponsors of the buildings, while hundreds of others are without enclosures. The use of a compound enclosure was intended to delineate the domain of the sacred properties and to protect the interior structures from natural and other threats [20]. Studies have indicated that the use of enclosures for monuments in Bagan started in the late 11th century A.D. [25], and the practice had been widely adopted in the 13th century A.D. [16]. Many of the enclosures have deteriorated over time, but some remain on par with the surrounding well-maintained monuments. Surveys conducted by Pichard [26] in Bagan identified monuments both inside and outside enclosures. The surveys accounted for around 938 monuments in 285 enclosures within MZ-1 from 1:10,000 scale maps in six volumes of inventory documents.

A large temple-monastic compound with double enclosures built in the 13th century A.D. near the village of "Min Nan Thu" in the hinterland of Bagan exhibits the set of components in an enclosure [20,27]. There, the donors set the temple and monastic structures, as well as other facilities, and planted toddy palms on land. Historical studies reported planting toddy palms by the donors for the following reasons: (1) Enriching the scenery of the religious compound [20], (2) provision of sweet liquor for a drink and making jaggery, and (3) the use of palm leaves for writing material and fan [28]. The statements reveal that the practice of growing such useful plants in the sacred compounds with the purpose of long-term use by religious people had been rooted since ancient times in Bagan. In other words, the land of Bagan reflects a habitat for scrub vegetation with sparse canopy cover in the drier part of Myanmar [29].

A recent validation of woody vegetation encroaching upon the land of MZ-1, and even into the surrounding area of monuments [8], sheds light on the management-related issue. If abandoned or no longer preserved, progressive growth of such vegetation is supposed to be detrimental to centuries-old architectural structures and scenery of the site. After being designated as World Heritage in July 2019, follow-up management of the entire site is of utmost importance to uphold Outstanding Universal Value (OUV) - universal importance of the cultural or natural heritage for all humankind [30]. In this regard, the involvement of multi-stakeholders, intrinsically local public, and regional government, will sustain the site management. The provision of practical and sophisticated information, on the other hand, is key for implementors, who rely on evidence-based data. To date, no information has 
yet been provided regarding the extent of coverage by specific vegetation types in the vicinity of monuments to foster preservation and landscape management.

Setting a focus on how the present condition of scrub vegetation interferes with the monuments in Bagan, the current study was an attempt of assessment on the scale of sacred compounds in MZ-1. The study first evaluated the tendency of the area occupied by specific components in sacred compounds, and secondly examined canopy coverage of scrub vegetation and associated growth corresponding to the subzones of MZ-1. The findings endorsed the extensive occurrence of scrub vegetation and the shrub-hosting area in the sacred compounds, and thus, revealed intensive site management as a priority. A realistic suggestion is to retain agricultural activities around the monuments in order to serve the integrity of the cultural landscape. Although the current study was carried out under some restrictions of local administrations, the results support information in considering the landscape management of the Bagan Cultural Heritage Site.

\section{Materials and Methods}

\subsection{Study Site}

The study site was Monumental Zone 1 (MZ-1) of the Bagan Cultural Heritage Site (Bagan) in the central Dry Zone of Myanmar (21.10-21.20 N, 94.85-94.92 E). Covering an area of 22,809.85 ha, Bagan comprises eight MZs and a buffer area [31]. Monumental Zone 1 is one of the eight MZs, housing 2348 variously-sized monuments built in the medieval and following eras along the eastern bank of the Ayeyarwady River over a total area of 4164 ha [8]. Seven residential areas are located on the plain topography of MZ-1 from north to south — three along the riverbank and four in the eastern hinterland (Figure 1a,b). Monumental Zone 1 also neighbors the two urban sites of Nyaung-U and New Bagan (Myo-thit). The 15,706 residents of MZ-1 [32] mainly subsist on farming. The farmlands surrounding the monuments are the blessing resources for abundant harvests of oilseed crops and pulses.

\subsection{Aerial Photography and Field Operations}

Aerial photographs of 13 random locations in MZ-1 were taken with a drone (DJI Phantom 4 Pro) during the rainy season from 9 to 18 September 2018, except in rainy and overly cloudy conditions, in order to sharply detect vegetation canopy and components in the sacred compounds. The selection of the location was through a check of the monument clusters appeared in the 11th, 12th, and 13th centuries A.D. based on previous archaeological studies $[16,18,33]$. The coordinates of the home points for take-off and landing were marked with a handheld Global Positioning System (GPS) unit (Oregon ${ }^{\circledR}$ 700, Garmin Ltd., Kansas, USA) in the World Geodetic System (WGS84) and accessed via Google Earth Maps ( $2 \mathrm{~m}$ resolution, UNES/Airbus) during a field survey. Points near monuments with a height of $25 \mathrm{~m}$ or more, residential areas, and other restricted zones were avoided based on the conditions of permission and instructions of the Nyaung-U township-government. Checks of monument heights were made using a Laser Rangefinder unit (TruPulse ${ }^{\circledR}$ 200, Laser Technology, Inc., Centennial, USA) before setting the home points.

Operations of drone flights with a Pix4D Capture unit (Pix4D S.A., Prilly, Switzerland) were under the following conditions: (1) A polygon-plan target area (11-14 ha) for capture of 2D RGB color composite images, (2) flight altitude of $70 \mathrm{~m}$, (3) camera (DJI FC6310) angled at $90^{\circ}$ perpendicular to the ground, (4) image overlapping adjustment ( $80 \%$ for each of the front and sides), (5) fast exposure for image capture from the moving drone, and (6) $80 \%$ of maximum speed $(2-8 \mathrm{~m} / \mathrm{s})$. The camera focal length was $9 \mathrm{~mm}$, the F35 equivalent was $24 \mathrm{~mm}$, and there was no flash applied. The flight mission set was synchronized automatically with a Pix4D Cloud upload in advance. During the flight, the telemetry of the craft was monitored on a mobile device to ensure mission activation. There was no operator's interruption, except in the event of sudden changes in cloud cover and wind speed.

In the flights, the craft captured 220-300 images with a resolution of $5472 \times 3648$ pixels $(2.5 \mathrm{~cm}$ resolution per pixel) for respective locations. The craft did not capture the images of home points 
outside the set polygon, and the built-in GPS of the DJI camera tagged all the pictures with geolocation data in the coordinate system (WGS84). In the 13 aerial composite-photographs, 27 sacred compounds (Figure 1a,b) were identified on the Google Earth Maps (2 m resolution, UNES/Airbus).

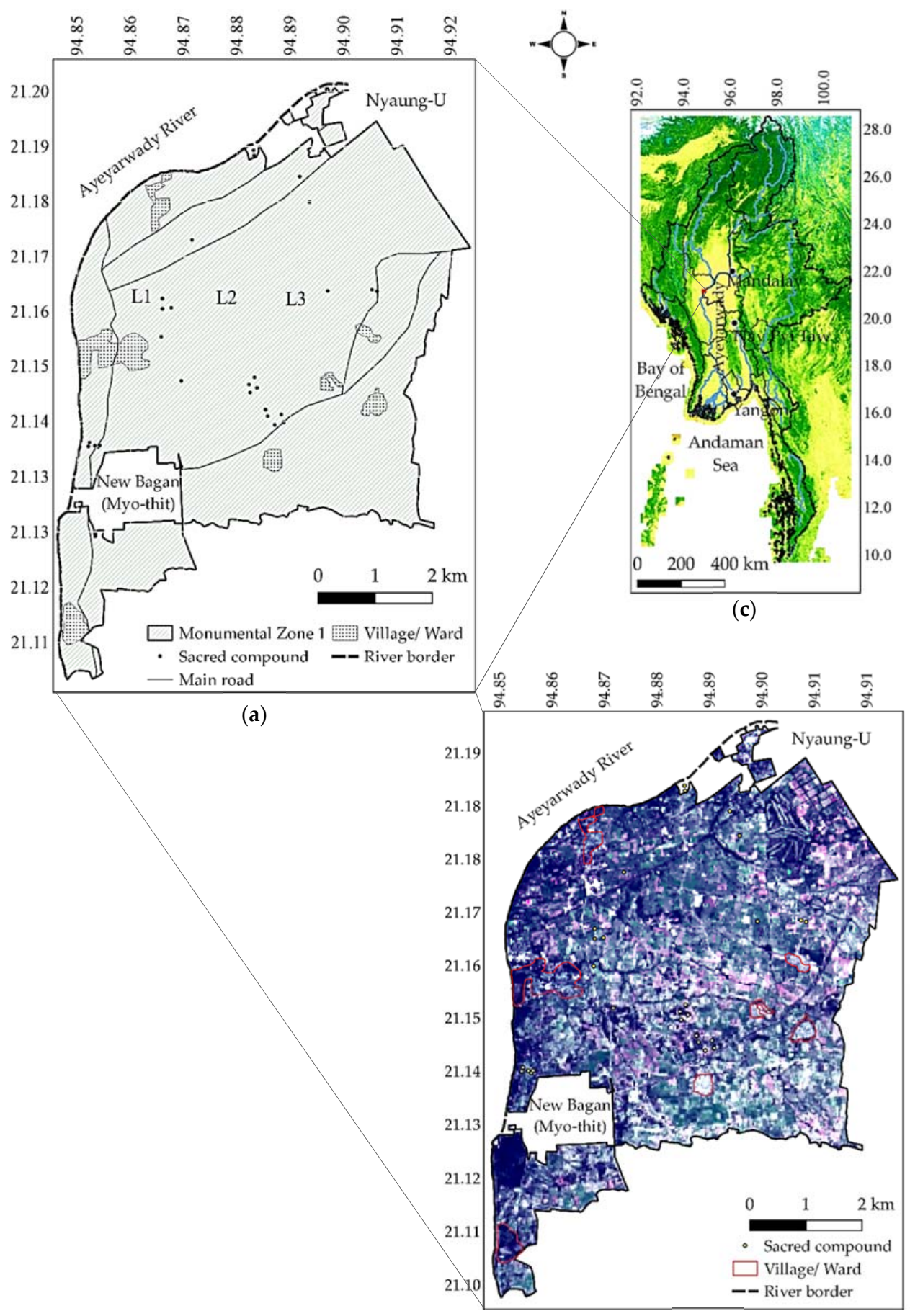

(b)

Figure 1. Location of 27 sacred compounds (survey sites) within Monumental Zone 1 (MZ-1) of the Bagan Cultural Heritage Site (a), Satellite image (15 m resolution) showing general features MZ-1 (b), Location of MZ-1 in Myanmar's Dry Zone (c). Note that the three subzones in MZ-1 are designated by distance from the Ayeyarwady River to eastern boundary-L1: $2 \mathrm{~km}$; L2: 2-3 km; and L3: 3-7 km. Source: [31,34-36]. 
At the post-flight mission stage, field inspections were performed in the sacred compounds, following the inventory maps and list of monuments produced by Pichard [26]. The underlying reason was to clarify the components in the sacred compounds during image analysis. The architectural style of monuments based on three major types (stupa, temple, and monastery) and unidentified structures, monument numbers, processed land (farmland, active monastic residences, and accessways), shrub-hosting patch, and scrub vegetation were noted in field surveys. Species of scrub vegetation and their geolocations in the sacred compounds were also recorded to verify them during the assessment of their canopy coverage.

\subsection{Image Processing and Analysis}

The drone-captured images were processed to generate GeoTIFF-encoded orthomosaic and digital surface model (DSM) raster imagery in Pix4D Mapper Pro Educational, Version 4.2.26 (Pix4D S.A., Prilly, Switzerland), which processed the geolocated images in three main steps:

1. Initial processing for calibrated and geolocated images,

2. Point cloud densification and generation of 3D texture mesh with optimal point density, and

3. DSM and orthomosaic image generations for the production of GeoTIFF-encoded raster images.

The 13 images from the orthomosaic and the DSM processings were applied to a Geographic Information System (QGIS, 3.4.2) with an overlay onto the MZ-1 map. Sacred compounds, monuments, processed land, shrub-hosting areas, and scrub-type plants were polygonized and subjected to surface area calculation. The surface areas were measured manually on orthomosaic images of high resolution ( $2.5 \mathrm{~cm}$ per pixel) in order to accurately determine occupancy of the components, following ground-truth records. Scrub-type plants partially covered the monuments were further assessed to evaluate the tendency of species to interfere with the monuments. Some distortions were observed at the margins of the orthomosaic imagery due to incomplete overlapping during the flight mission, though they did not affect the data on the sacred compounds targeted in the study.

A prior check on scrub vegetation and the other components was applied to the orthomosaic images. On this basis, three subzones were designated by overlaying grids of $1 \mathrm{~km}^{2}$ onto the MZ-1 map. The designation was within $7 \mathrm{~km}$ from the bank of the Ayeyarwady River to the eastern boundary of MZ-1, to distinguish the three subzones: L1 (within $2 \mathrm{~km}$ ), L2 (within 2-3 km), and L3 (within 3-7 km) (Figure 1a). In each subzone, land coverage by individual components and the associated presence of scrub vegetation in the compounds were further examined.

\subsection{Data Analysis}

The surface areas of components were assessed for comparative analysis of occupancy on the land of the sacred compounds. Mean, maximum, and minimum values were computed for overall occupied areas of the components in 27 compounds, and the area of the scrub vegetation canopy partially covering the monuments was determined. In addition, subzone-dependent areas covered with scrub vegetation were assessed by two-way variance analysis (ANOVA) using the general linear model (GLM) procedure at $\alpha=0.05$ (SAS University Edition). Based on the interaction between the subzone and the scrub vegetation canopy cover area, exploratory factor analysis was implemented to clarify links between the presence of mutual species corresponded to the subzones.

\section{Results}

\subsection{Relative Areas of Components in Sacred Compounds}

At the study site, 27 sacred compounds occupied a total of 22.36 ha $(0.54 \%$ of MZ-1), with a mean size of 0.83 ha (Table 1 ). The compounds largely deviated in size over seven orders of magnitude between the minimum and maximum. In the sacred compounds, the components-monuments, processed land, shrub-hosting areas, and scrub vegetation-accounted for relative coverage areas 
of $6.9 \%, 25 \%, 40.6 \%$, and $27.5 \%$ of the compounds, respectively. The absolute occupancy of the 89 monuments observed in the 27 compounds was 1.55 ha, with a considerable diversion of the mean from the lowest and highest values. The data presented monuments of various sizes scattered across the study site and less than $10 \%$ of land occupied by monuments in the compounds. Meanwhile, land parcels characterized by anthropogenic influences, shrub-hosting patches, and scrub vegetation represented areas in the range of $25 \%-40 \%$. Although processed lands were present in some compounds, many areas were found to be undisturbed and under vegetation cover.

Table 1. Land occupancy of monuments, processed land and shrub-hosting areas, and canopy cover of scrub vegetation in 27 sacred compounds of MZ-1, Bagan Cultural Heritage Site.

\begin{tabular}{|c|c|c|c|c|c|}
\hline \multirow{2}{*}{ Component } & \multirow{2}{*}{$\mathbf{N}$} & \multicolumn{3}{|c|}{ Area (ha) } & \multirow{2}{*}{$\%$ Sacred Compound } \\
\hline & & Total & Mean $\left(\times 10^{-4}\right)$ & Range $\left(\times 10^{-4}\right)$ & \\
\hline 1. Monuments $^{+}$ & 89 & 1.55 & 173.81 & $3.51-1197.48$ & 6.92 \\
\hline 2. Processed land & 36 & 5.59 & 1553.84 & $4.41-14,497.76$ & 25.02 \\
\hline Farmland & 4 & 3.44 & 8591.27 & $4832.59-14,497.76$ & 15.38 \\
\hline Active monastic residences & 6 & 1.31 & 2181.00 & $775.47-3489.60$ & 5.86 \\
\hline Accessways & 26 & 0.84 & 311.06 & $4.41-1640.33$ & 3.76 \\
\hline 3. Shrub-hosting areas & 90 & 9.08 & 1008.70 & $1.95-14,063.77$ & 40.60 \\
\hline 4. Scrub vegetation & 1119 & 6.14 & 54.88 & $1.02-2390.33$ & 27.46 \\
\hline Acacia leucophloea & 156 & 1.02 & 65.42 & $3.02-645.19$ & 4.56 \\
\hline Acacia catechu & 25 & 0.06 & 24.56 & $3.19-66.09$ & 0.27 \\
\hline Azadirachta indica & 119 & 0.31 & 26.24 & $1.09-250.02$ & 1.40 \\
\hline Zizyphus jujuba & 212 & 0.35 & 16.72 & $1.02-157.99$ & 1.58 \\
\hline Osyris wightiana & 38 & 0.04 & 11.16 & $2.84-43.74$ & 0.19 \\
\hline Euphorbia antiquorum & 35 & 0.05 & 13.64 & $2.95-51.80$ & 0.21 \\
\hline Prosopis juliflora & 356 & 3.60 & 102.34 & $1.24-2390.33$ & 16.29 \\
\hline Other ${ }^{++}$ & 178 & 0.66 & 37.03 & $1.68-467.01$ & 2.95 \\
\hline Sacred compounds & 27 & 22.36 & 8281.51 & $870.96-62,086.24$ & $100.00^{t++}$ \\
\hline
\end{tabular}

Notes: ${ }^{\dagger} 89$ monuments consisting of 33 stupas, 30 temples, 24 monasteries, and 2 other architectural structures in 27 sacred compounds. ${ }^{++}$Planted ornamentals, palms, fruit trees, and unknown species (see Table 2). ${ }^{+++}$Sum of 1,2 , 3 and $4 . \mathrm{N}=$ Number of observational units.

Table 2. Scrub vegetation observed in sacred compounds of MZ-1, Bagan Cultural Heritage Site.

\begin{tabular}{|c|c|c|c|}
\hline Common (Local) Name & Scientific Name & Family & Habit \\
\hline 1. Tanaung & Acacia leucophloea (Roxb.) Willd. & Fabaceae & Tree \\
\hline 2. Sha & Acacia catechu Willd. & Fabaceae & Tree \\
\hline 3. Tama & Azadirachta indica A. Juss. & Meliaceae & Tree \\
\hline 4. $\mathrm{Zi}$ & Zizyphus jujuba Lam. & Rhamnaceae & Tree \\
\hline 5. Zaung-gyan & Osyris wightiana Wall. & Santalaceae & Shrub \\
\hline 6. Tazaung-gyi & Euphorbia antiquorum L. & Euphorbiaceae & Small tree \\
\hline 7. Gandayasein & Prosopis juliflora DC. & Fabaceae & Tree \\
\hline \multicolumn{4}{|l|}{ 8. Other } \\
\hline $\mathrm{Htan}^{\dagger}$ & Borassus flabellifer $\mathrm{L}$. & Arecaceae & Tree \\
\hline $\mathrm{Ohn}^{+}$ & Cocos nucifera $\mathrm{L}$. & Arecaceae & Tree \\
\hline Ma-gyi $^{+}$ & Tamarindus indica L. & Caesalpiniaceae & Tree \\
\hline Tha-yet $^{\dagger}$ & Mangifera indica L. & Anacardiaceae & Tree \\
\hline Sakku-pan ${ }^{\dagger}$ & Bougainvillea spp. & Nyctaginaceae & Climber \\
\hline Unknown $^{\dagger}$ species & - & - & - \\
\hline
\end{tabular}

Note: ${ }^{+}$The species referred to here as "Other". Source: [11].

The processed land at the study site consisted of farmland, active monastic residences, and accessways. Within the total area of the 27 sacred compounds, farmland accounted for $15.4 \%$, and each of monastic residences and accessways accounted for less than $10 \%$. The data revealed that the usage of processed land for farming as a principal human-influenced component coexisted with active settlements of religious personnel and tracks within the compounds.

Scrub vegetation chiefly consisted of eight species (Table 2), whose overall coverage was 6.14 ha, representing $27.5 \%$ of sacred compound areas (Table 1). Among these species, the canopy cover of Prosopis juliflora had the most substantial proportion of the total at $16.3 \%$, while the remaining species 
accounted for less than $5 \%$. Each species was characterized by a wide range of minimum to maximum canopy cover data, resulting in a high variation of dimensions.

Six of the eight species had canopy partially covered the monuments in sacred compounds (Table 3). The total coverage of these types (Acacia leucophloea, Acacia catechu, Azadirachta indica, Zizyphus jujuba, P. juliflora, and "Other") accounted for $1.6 \mathrm{ha}$, with a mean of $1.31 \times 10^{-2}$ ha. The tendency of the P. juliflora spread produced a canopy cover of $78 \%$, making it the main species in direct contact with the monuments. Acacia leucophloea, "Other" and A. indica accounted for 11.6\%, 5.4\%, and 3.3\%, respectively, while $A$. catech $u$ and $Z$. jujuba resulted in less than $1 \%$. The species which partially covered the monuments combined in formations from small individual instances to groups, creating significant canopy cover (Figure 2). The results suggested that introduced species, rather than native scrub-type plants had more considerable proximity to the monuments, creating partial shade.

Table 3. Canopy area of scrub vegetation partially covering monuments in sacred compounds of MZ-1, Bagan Cultural Heritage Site.

\begin{tabular}{cccccc}
\hline \multirow{2}{*}{ Scrub Vegetation } & \multirow{N}{*}{} & \multicolumn{3}{c}{ Area (ha) $\left(\times \mathbf{1 0}^{-\mathbf{4}}\right)$} & \multirow{2}{*}{ \% Grand Total } \\
\cline { 3 - 5 } & & Total & Mean & Range & \\
\hline A. leucophloea & 20 & 1883.82 & 125.59 & $12.48-344.03$ & 11.56 \\
A. catechu & 3 & 88.26 & 29.42 & $6.08-59.31$ & 0.54 \\
A. indica & 11 & 538.64 & 48.97 & $2.88-250.02$ & 3.31 \\
Z. jujuba & 10 & 158.22 & 15.82 & $0.98-50.17$ & 0.97 \\
P. juliflora & 62 & $12,747.08$ & 205.60 & $1.32-2390.33$ & 78.24 \\
“Other" & 18 & 876.25 & 48.68 & $7.22-199.39$ & 5.38 \\
Grand total & 124 & $16,292.27$ & 131.39 & $1.32-2503.11$ & 100 \\
\hline
\end{tabular}

Note: $\mathrm{N}=$ Number of observational units.

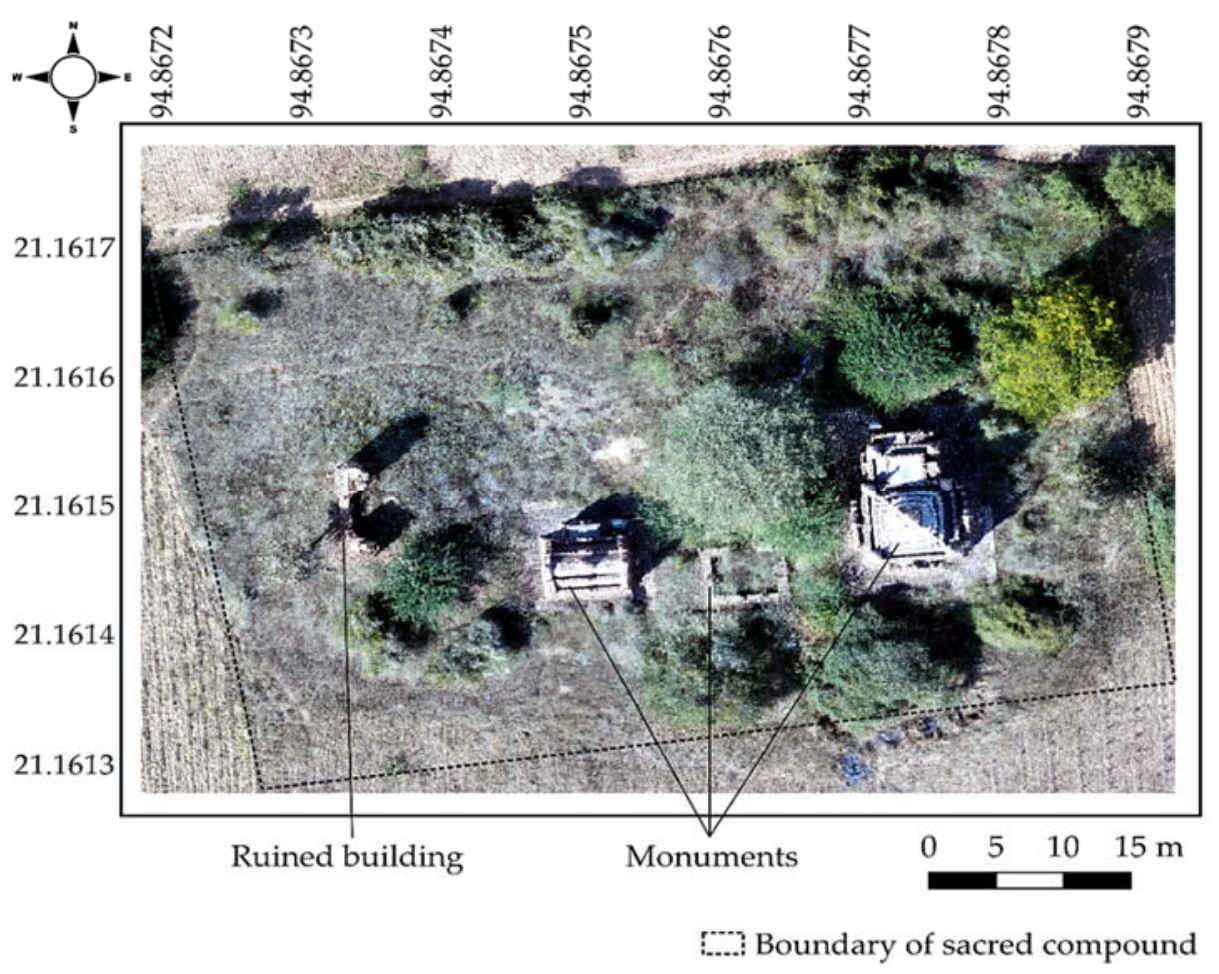

(a)

Figure 2. Cont. 


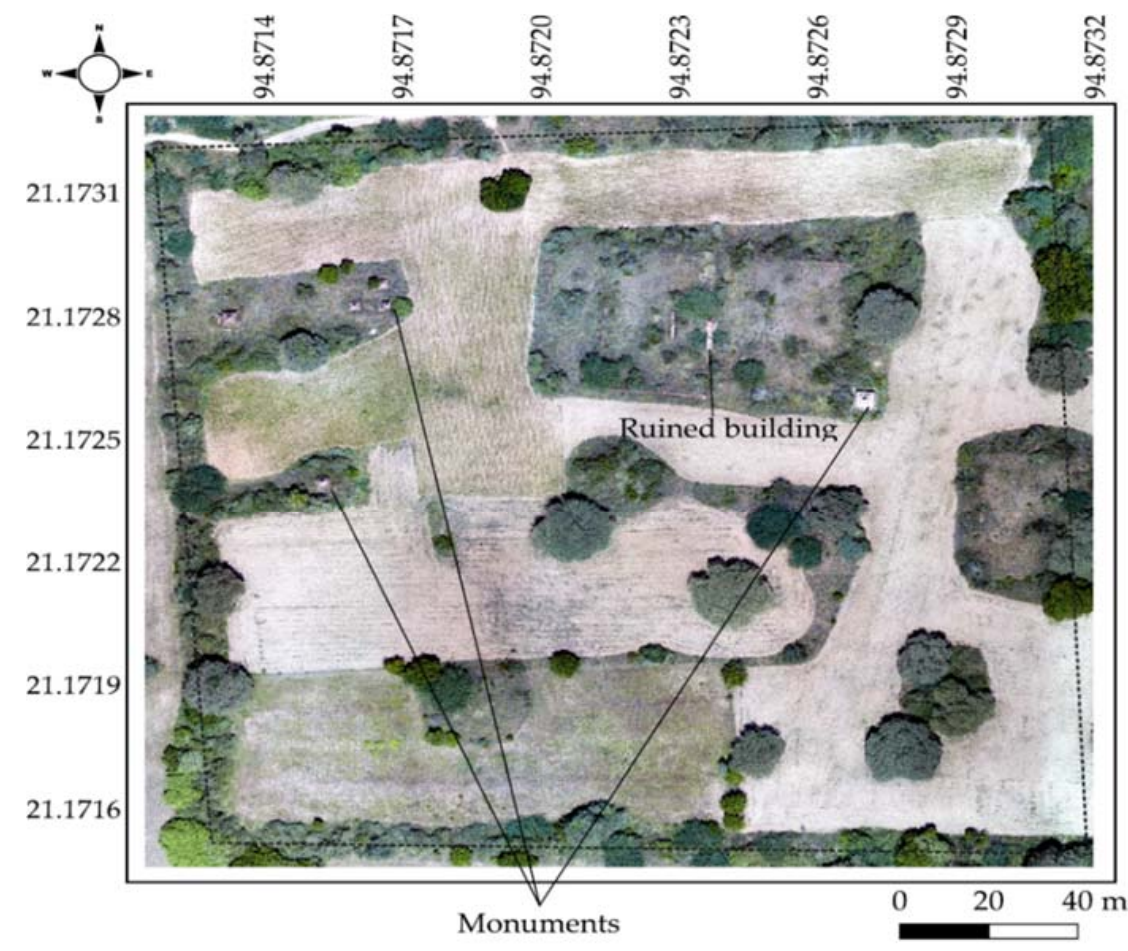

B.... Boundary of sacred compound

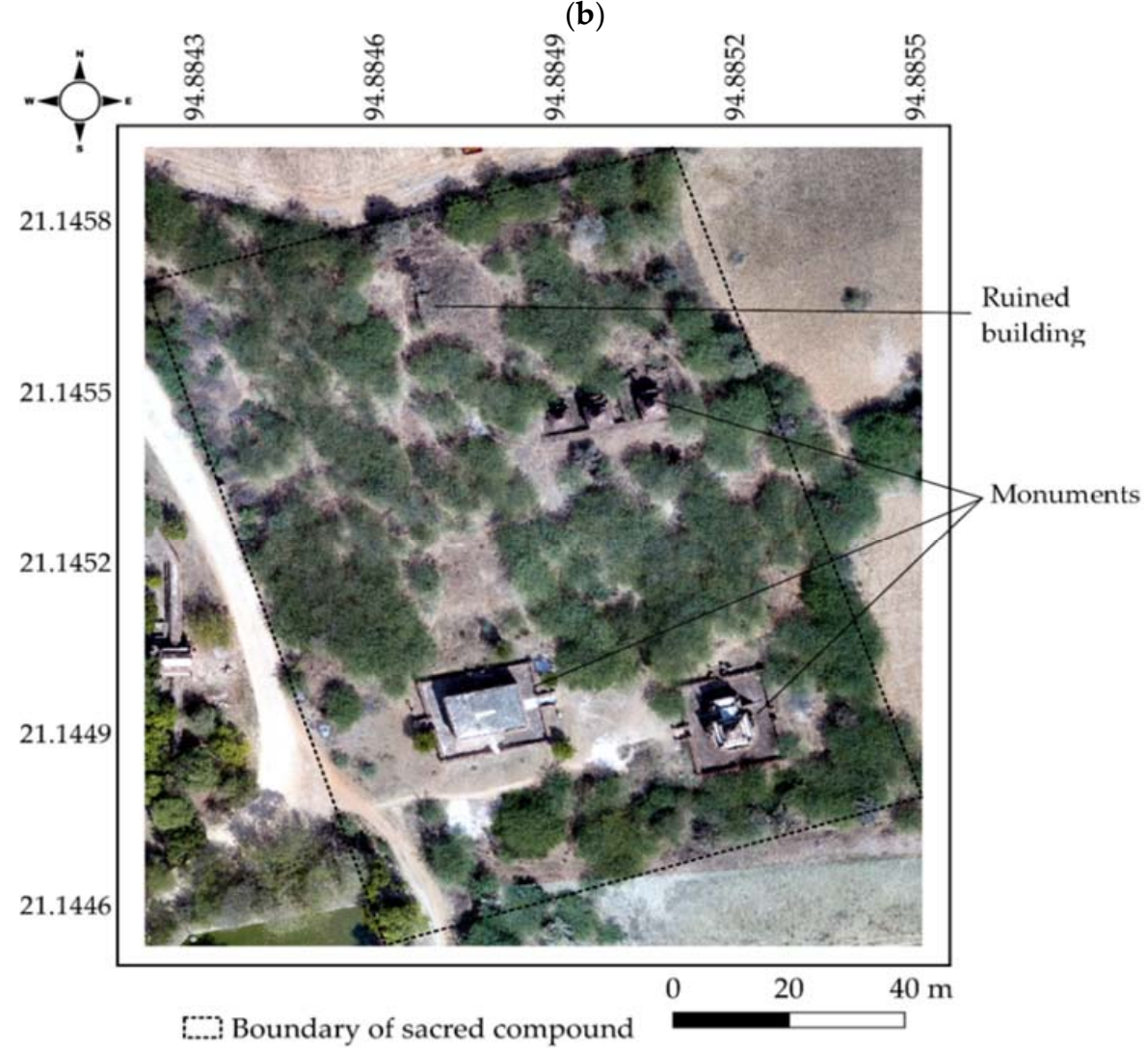

(c)

Figure 2. Representations of vegetation conditions around monuments and ruins in sacred compounds in the three subzones: (a) $2 \mathrm{~km}$, (b) 2-3 km, and (c) 3-7 km from the Ayeyarwady River to the eastern boundary of MZ-1 in the Bagan Cultural Heritage Site. 


\subsection{Coverage of Other Components and Scrub Vegetation Canopy in the Three Subzones}

In the designation of the three subzones (L1, L2, and L3) based on the distance from the Ayeyarwady River to the eastern boundary of MZ-1, 11, 4, and 12 sacred compounds in zones L1, L2 and L3, respectively. In the compounds, monuments occupied $4.5 \%, 0.8 \%$, and $2.6 \%$ of the land, respectively (Figure 3). Processed land in the three zones accounted for $13 \%-18 \%$ of the total area, while shrub-hosting areas ranged from 3\% to 38\%. The processed land area of 3.6 ha in L2 was twice as large as that of L3, and an order of magnitude larger than that of L1. In L3, meanwhile, the shrub-hosting area of around 5 ha was 1.7 times larger than that of L2 and 3.8 times larger than that of L1. The scrub vegetation coverage of 3.65 ha in L3 was twice as broad as that of L2 and four times as wide as that of L1. The data implied that, although the sacred compounds in L3 were wider than those in the other two subzones, shrub-hosting areas occupied the majority of the land there. In L2, processed areas, mainly farmland, tended to be more prominent than other components, while no farmland occupied the compounds in L1 and L3.

The results of the two-way factorial analysis regarding the scrub vegetation canopy coverage against the subzones highlighted significant effects for each parameter and revealed a related interaction (Table 4). In L3, the mean canopy cover of the eight scrub-type species considerably exceeded those of L1 and L2, whereas there was non-obvious discrimination between the latter two. Of the eight plant types, P. juliflora was among the leaders in terms of canopy coverage, along with $A$. leucophloea, A. catechu, A. indica, and "Other." The land area covered by the P. juliflora canopy was 6.1, 9.2, and 7.5 times larger than that covered by Z. jujuba, O. wightiana, and E. antiquorum, respectively.

Table 4. ANOVA scores for mean scrub vegetation coverage areas in sacred compounds in three subzones designated by distance from the Ayeyarwady River within MZ-1 at Bagan.

\begin{tabular}{|c|c|c|c|c|c|c|c|c|c|}
\hline \multirow{2}{*}{$\begin{array}{l}\text { Sub- } \\
\text { zone }\end{array}$} & \multicolumn{8}{|c|}{ Scrub Vegetation Coverage Area (ha) $\left(\times 10^{-4}\right)$} & \multirow[b]{2}{*}{ Mean } \\
\hline & $\begin{array}{c}\text { A. } \\
\text { leucophloea }\end{array}$ & $\begin{array}{c}A . \\
\text { catechu }\end{array}$ & A. indica & Z. jujuba & $\begin{array}{c}O . \\
\text { wightiana }\end{array}$ & $\begin{array}{c}E . \\
\text { antiquorum }\end{array}$ & $\begin{array}{c}P . \\
\text { juliflora }\end{array}$ & "Other" & \\
\hline L1 & $\begin{array}{c}90.22 \mathrm{a} \\
( \pm 16.73)\end{array}$ & $\begin{array}{l}18.89 \mathrm{a} \\
( \pm 4.11)\end{array}$ & $\begin{array}{l}24.90 \mathrm{a} \\
( \pm 9.90)\end{array}$ & $\begin{array}{l}11.03 \mathrm{~b} \\
( \pm 1.16)\end{array}$ & $\begin{array}{c}7.46 \mathrm{~b} \\
( \pm 1.42)\end{array}$ & $\begin{array}{l}11.79 \mathrm{a} \\
( \pm 2.29)\end{array}$ & $\begin{array}{l}36.92 \mathrm{~b} \\
( \pm 4.46)\end{array}$ & $\begin{array}{l}19.66 \mathrm{~b} \\
( \pm 3.00)\end{array}$ & $\begin{array}{l}30.22 \mathrm{~B} \\
( \pm 2.91)\end{array}$ \\
\hline $\mathrm{L} 2$ & $\begin{array}{l}71.42 \mathrm{ab} \\
( \pm 8.95)\end{array}$ & $\begin{array}{c}29.47 \mathrm{a} \\
( \pm 10.01)\end{array}$ & $\begin{array}{l}22.47 \mathrm{a} \\
( \pm 5.18)\end{array}$ & $\begin{array}{l}19.52 \mathrm{a} \\
( \pm 2.48)\end{array}$ & $\begin{array}{c}8.38 \mathrm{~b} \\
( \pm 1.23)\end{array}$ & $\begin{array}{l}13.49 \mathrm{a} \\
( \pm 3.48)\end{array}$ & $\begin{array}{l}68.42 \mathrm{ab} \\
( \pm 11.85)\end{array}$ & $\begin{array}{c}47.31 \mathrm{a} \\
( \pm 11.14)\end{array}$ & $\begin{array}{l}43.82 \mathrm{~B} \\
( \pm 3.97)\end{array}$ \\
\hline L3 & $\begin{array}{c}47.11 \mathrm{~b} \\
( \pm 10.57)\end{array}$ & $\begin{array}{l}31.59 \mathrm{a} \\
( \pm 7.02)\end{array}$ & $\begin{array}{l}34.74 \mathrm{a} \\
( \pm 8.57)\end{array}$ & $\begin{array}{l}18.36 \mathrm{a} \\
( \pm 1.75)\end{array}$ & $\begin{array}{l}21.86 \mathrm{a} \\
( \pm 4.58)\end{array}$ & $\begin{array}{l}14.26 \mathrm{a} \\
( \pm 2.37)\end{array}$ & $\begin{array}{l}149.77 \mathrm{a} \\
( \pm 26.07)\end{array}$ & $\begin{array}{l}41.84 \mathrm{ab} \\
( \pm 6.47)\end{array}$ & $\begin{array}{r}78.97 \mathrm{~A} \\
( \pm 10.60)\end{array}$ \\
\hline Mean & $\begin{array}{c}65.42 \mathrm{AB} \\
( \pm 6.63)\end{array}$ & $\begin{array}{c}24.56 \mathrm{AB} \\
( \pm 3.56)\end{array}$ & $\begin{array}{c}26.24 \mathrm{AB} \\
( \pm 4.14)\end{array}$ & $\begin{array}{l}16.72 \mathrm{~B} \\
( \pm 1.21)\end{array}$ & $\begin{array}{l}11.16 \mathrm{~B} \\
( \pm 1.60)\end{array}$ & $\begin{array}{l}13.64 \mathrm{~B} \\
( \pm 1.64)\end{array}$ & $\begin{array}{l}102.34 \mathrm{~A} \\
( \pm 13.77)\end{array}$ & $\begin{array}{c}37.00 \mathrm{AB} \\
( \pm 4.24)\end{array}$ & \\
\hline
\end{tabular}

Notes: Values are means \pm standard errors. The main effects of subzone and scrub vegetation coverage are significant $(p<0.0001)$, and related interaction is observed $(p=0.016)$ at $\alpha=0.05$. Means with different letters in the same columns are significantly different $(p<0.05)$ based on Tukey's studentized range test at $\alpha=0.05$. L1: $2 \mathrm{~km}$; L2: 2-3 km; L3: 3-7 km from the Ayeyarwady River.

While there were similarities in the mean canopy coverage of $A$. catechu, $A$. indica, and E. antiquorum among the three locations, the land covered by A. leucophloea in L1 was about twice the size of that in L3. In L1, the area covered by A. leucophloea was indistinguishable from that of L2; the latter, in turn, was equivalent to the mean in L3. The area covered by Z. jujuba in L1 was 1.7 and 1.8 times smaller than that in L2 and L3, respectively, while the magnitudes in the latter two were similar. In L3, O. wightiana covered around three times as much of the sacred compounds as in L1 and L2, while its coverage was similar in the latter two. Canopy coverage of P. juliflora in L3 was four times larger than that in L1, while similarities resulted in the coverage areas between L2 and L3, and L1 and L2. The canopy of "Other" in L2 was 2.4 times larger than that in L1, while coverage between L1 and L3, and L2 and L3, did not differ significantly.

The results indicated more scrub vegetation canopy cover in L3 than in the other two subzones. The seven types other than A. leucophloea dominated the overall canopy coverage in the sacred compounds in L3, thereby enlarging the overall magnitude. While coverage with these plant types likely represented a small contribution to the compounds in L1, the situation in L2 was somewhat 
in between. In such a context, L2 can represent a transition zone regarding scrub vegetation canopy coverage in the sacred compounds.

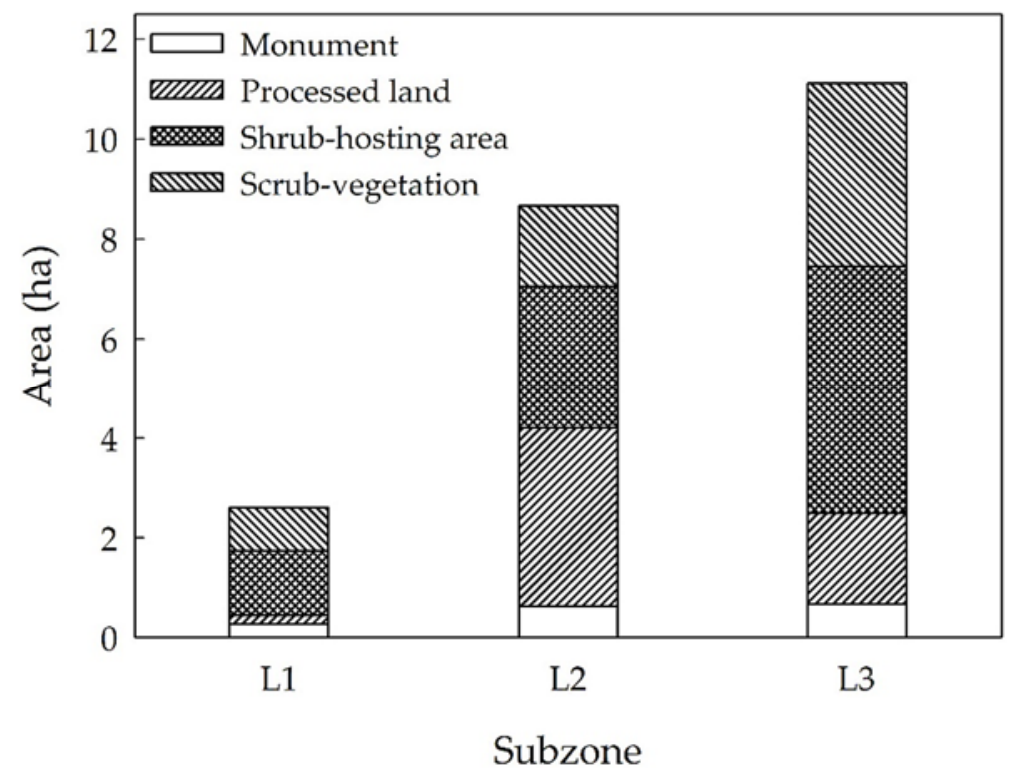

Figure 3. Coverage by monuments, processed land, shrub-hosting areas, and scrub vegetation in sacred compounds in three subzones (L1: $2 \mathrm{~km}$; L2: 2-3 km; L3: 3-7 km by the distances from the Ayeyarwady River) within MZ-1 on the Bagan site.

\subsection{Factors Influencing the Occurrence of Each Scrub Vegetation Type}

Based on the interactive results regarding relationships between subzone and scrub vegetation canopy coverage, the exploratory factor analysis indicated maximum relations within plant types concerning maximum variance among factors. Three factors with respective eigenvalues of 2.04, 1.38, and 0.97 were considered for an overall variance of $55 \%$ (Table 5). The importance of Factor 1 expressed as $38.8 \%$, to which A. leucophloea, A. indica, and Z. jujuba contributed factor loadings above $50 \%$. Due to loading of over $80 \%$, A. indica was enormously attributed to Factor 1, while Z. jujuba and A. leucophloea were also of high importance to this factor. These three types characterized a similar presence in the sacred compounds. For the attribution of A. leucophloea to Factor 1, the significance of its canopy coverage in L1 and L2 (Table 4) revealed underlying subzone factors within $2 \mathrm{~km}$ and 2-3 km from the Ayeyarwady River.

Table 5. Factor loadings of scrub vegetation in sacred compounds within MZ-1 of Bagan.

\begin{tabular}{cccc}
\hline Scrub Vegetation & $\begin{array}{c}\text { Factor 1 (38.81\%) } \\
\text { (Eigenvalue }=\mathbf{2 . 0 4})\end{array}$ & $\begin{array}{c}\text { Factor 2 (36.90\%) } \\
\text { (Eigenvalue = 1.38) }\end{array}$ & $\begin{array}{c}\text { Factor 3 (24.29\%) } \\
\text { (Eigenvalue = 0.97) }\end{array}$ \\
\hline A. leucophloea & 0.595 & 0.241 & -0.109 \\
A. catechu & 0.164 & 0.597 & -0.402 \\
A. indica & 0.829 & -0.045 & 0.084 \\
Z. jujuba & 0.685 & -0.031 & -0.058 \\
O. wightiana & 0.025 & 0.641 & 0.204 \\
E. antiquorum & -0.054 & 0.729 & 0.154 \\
P. juliflora & -0.022 & 0.171 & 0.870 \\
"Other" & 0.408 & 0.484 & -0.249 \\
\hline
\end{tabular}

Notes: Overall variance explained by three factors accounts for $55 \%$. Proportions expressed and eigenvalues based on individual factors are indicated in parentheses. 
In Factor 2, with 36.9\% contribution, $A$. catechu, O. wightiana, and E. antiquorum exhibited loadings of $60 \%, 64 \%$, and $73 \%$, respectively. The canopy-covered areas of these three types were remarkably large in L3 (Table 4), and their close relationship, as explained by Factor 2, corresponded to sacred compounds within a distance of 3-7 km from the river. For almost 50\% loading, "Other" likely accounted for its associated presence with A. catechu, O. wightiana, and E. antiquorum, but related ascription appeared inconspicuous.

Expressed as $24.3 \%$ for Factor 3, P. juliflora showed a notable loading of $87 \%$ in this factor, exhibiting inferior relationship with other plant types. The canopy of this type covered extensive areas of sacred compounds in L3, as with L2 (Table 4). This species was consistently the scrub-type plant most prevalent in sacred compounds within 3-7 km of the river, and also occurred to a certain extent in those within $2-3 \mathrm{~km}$.

Concerning the close relationships linking scrub vegetation, the underlying factors helped to elucidate the importance of the subzone in which the sacred compounds are present. The subzone within $2 \mathrm{~km}$ from the Ayeyarwady River represented the Riverside Zone, where A. leucophloea, A. indica, and Z. jujuba were prominent in sacred compounds. The hinterland zone within 3-7 km was under the influence of P. juliflora, A. catechu, O. wightiana, and E. antiquorum, and represented the Inland Zone. In between was the region within $2-3 \mathrm{~km}$, where the extent of scrub-type species exhibited transience in terms of canopy cover and represented the Transition Zone. Scrub vegetation in sacred compounds reflected the vegetated conditions of the subzone within the landscape scale of MZ-1.

\section{Discussion}

\subsection{Components Integrating into Sacred Compounds}

In this study, the sacred compounds within MZ-1 enclosed religious monuments built between the 12th and 14th centuries A.D. These periods covered major construction eras of monuments in Bagan, i.e., 12th-13th centuries A.D., while further constructions continued to the 19th centuries A.D. [16,26]. The overall area of the 27 compounds examined was 22.36 ha, encompassing monuments of three major types (33 stupas, 30 temples, and 24 monasteries) and two unidentifiable structures. The monuments occupied the land from small to large areas ranging from 3.5 to $1197.5\left(\times 10^{-4}\right)$ ha (Table 1). The minimum coverage involved the presence of a small stupa, whereas the maximum was associated with the ruins of a monastery. As an area measurement was manually conducted in this study to assess the land covered by main monument structures and any related extensions, the dimensions observed somewhat deviated from the general size range presented by Pichard [37]. Nevertheless, the data reflects the scattering of the small, medium, and large monuments in the 27 sacred compounds within MZ-1. Temples were only found in 17 compounds, monasteries only in 16 , stupas in seven, and unidentifiable structures in two, while temples and monasteries were found together in most of the compounds. The 27 sacred compounds encompassing the 89 monuments examined in this study represented approximately one-tenth of the numbers identified in Pichard's survey [26].

In the sacred compounds, land coverage by monuments was around $7 \%$, while those of other components (processed land, shrub-hosting areas, and scrub vegetation) were 3.6 to 5.8 times larger. The data implied that a large proportion of land was under human intervention and vegetated conditions. Farmland, active monastic residences, and accessways were under anthropogenic influence in the current study. The relative coverage of processed land in the compounds corresponded to that of the subzones, accounting for $41.3 \%$ in L2, 16.5\% in L3, and 7.3\% in L1 (Figure 3). The subzones reflected the characteristics of land east of the Ayeyarwady River to the hinterland. In the hinterland (L2 and L3), the data expressed more remarkable human interventions to the compounds than the subzone in the vicinity of the river. Such a condition was probably due to the presence of the large compounds in the hinterland (Figure 3) and their limited coverage by monuments, thus rendering the remaining space subject to use for agriculture and other purposes. 
In a historical context, the hinterland area was a site where constructions of gigantic temples and monastic structures with broad ground-plan (50 m and above) during the 12th and 13th centuries A.D. $[18,26]$. It seemed that the religious buildings built in the 11th century A.D., which were of smaller size (12 $\mathrm{m}$ or less ground-plan), had populated the riverside, thereby pushing later constructions eastward to the hinterland. Hudson et al. [16] also described how it was a peak of monastic constructions with other related buildings in a single compound during the 13th century A.D.; hence, the large sacred compounds emerged through such cultural activities. The archaeological evidence also supports the scatter of monuments in Bagan based on the three constructions periods-11th, 12th, and 13th centuries A.D. [16,33]; the latter two periods were the times of building monuments in the hinterland. The documents were in line with the current study in the context of the existence of large-sized temples or monasteries in massive sacred compounds in the hinterland. Although some monuments were under conservation, some were somewhat abandoned and ruined inside the enclosures deteriorated. Over the deteriorated enclosure-wall, there occurred scrub vegetation as a live hedgerow for the monuments inside. Nonetheless, the uncontrolled growth of such vegetation increases the threat to the monuments in the vicinity. Site management to let the vegetation grow under a controlled state is, therefore, a requirement to preserve the monuments and retain the integrity of the entire heritage site.

In the sacred compounds in L2, the influence of farmland reflected the agricultural activity of local farmers residing in the rural settlements within MZ-1 (Figure 2b; Figure 1a,b). It implied that cultivation activity may have suppressed the incidence of non-crop vegetation in the compounds. Continuous cultivations, then, would restrict the expansion of shrub-hosting areas. Instead, lack of cultivation or other types of processed land would enhance the incidence of weedy vegetation, thereby enlarging the shrub-hosting area, particularly in the sacred compounds of the hinterland. In the absence of any cropping or if land becomes abandoned, this would create shrub or grass cover in the compounds. A recent study by the authors of [8] described the habitation of shrubs and other weedy vegetation on the farmland without crop cover in MZ-1. The authors of $[38,39]$ also stated that abandoned agricultural land is the site vulnerable to the conquest of annual and perennial plant species. The current study, therefore, suggests that the presence of farmland in the sacred compounds is a control measure for weedy growth and regeneration of scrub vegetation, thereby representing the managed part of the living landscape.

A query on administrations in Myanmar's history described that the agricultural lands were present in the surrounding of some temples in MZ-1 in the Bagan era [21]. The substantial dedications of donors to the religious buildings and personnel (the religious body) during the 12th and 13th centuries A.D., and the glebe lands and labors were mainly loyal to the religious body $[40,41]$. The laborers were responsible for taking care of the dedicated items, and they might have cultivated the glebe lands during those days. Besides, some five settlements existed within MZ-1 during the Pre-Bagan and Bagan eras [16,17], and the residents supposedly cultivated the lands for their living in those periods. Reports on extensive use of sesamum oil for cooking and lighting, and cultivations of grain crops like millet and sorghum $[23,24]$ supported the context of farmland present around the religious buildings in the ancient times. Later on, the successors of the Bagan land seemed to proceed cultivations through several centuries, and the practices developed would have contributed to the characteristics of the Bagan landscape.

As discussed earlier, the components in each sacred compound are integral to the significance of the cultural heritage site. The monuments indeed symbolize the cultural heritage on the one hand, and managing the vegetation cover in the surrounding is inevitable to conserve the entire site on the other hand. In this regard, contributions of multi-stakeholders from different fields with concrete policy implications are believed to safeguard the World Cultural Heritage in Bagan.

\subsection{Scrub Vegetation Canopy Coverage against Subzones}

In the study site, scrub vegetation occupied considerable areas of sacred compounds and was comprised of native and invasive species. The native scrub vegetation in Myanmar is of tropical 
dry (thorn) forest type [9,10,42], and invasive P. juliflora [10] also grows extensively all over the Dry Zone [43,44]. Among the scrub-type plants, land coverage by P. juliflora ranked highest, though some native species and "Other" displayed similarities in coverage (Table 4). Prosopis juliflora was also a species with notably high canopy expansion in contact with the monuments (Table 3). However, the native A. leucophloea exhibited an opposite trend to P. juliflora. The former had high coverage in L1, while the latter did in L3. The results stressed the relation between subzone and scrub vegetation canopy coverage, indicating that A. leucophloea was abundant in sacred compounds close to the river, whereas $P$. juliflora influenced the hinterland. In between in L2, both species tended to switch between respective expansion and shrinkage of canopy coverage, representing a transition zone at the study site. While coverage by other native species remained unchanged with location, Z. jujuba, O. wightiana, and "Other" exhibited sparse coverage in L1, generally increasing toward the hinterland. These conditions were considered to have triggered enlargement of the overall area of coverage by scrub vegetation in the scared compounds of L3. The argument suggests that drier land seemingly favored the growth of P. juliflora and native scrub species other than A. leucophloea in sacred compounds.

However, the presence of $A$. leucophloea in the compounds was associated with the growth of A. indica and Z. jujuba, while A. catechu coexisted with O. wightiana and E. antiquorum (Table 5). Interestingly, $P$. juliflora was a peculiar species irrespective of others present in the same habitat. The results implied that some scrub-type plants grow synergistically with certain species, while antagonizing others. This context further extends to the influence of other abiotic and biotic factors relating to the survival of such plants. The L2-L1 subzones stretched to the river may favor the presence of A. leucophloea, A. indica, and Z. jujuba.

On the contrary, toward the hinterland, L2-L3 may benefit the associated growth of $A$. catechu, O. wightiana, and E. antiquorum, and undoubtedly P. juliflora. The transition zone, L2, characterized overall coverage of scrub vegetation equivalent to the situation in the proximity of the river. Despite a broader tendency of occupation in the sacred compounds, the equivalence of scrub vegetation canopy coverage in L2 to L1 was the attribute to inference from extensive human intervention. It appears to be a characteristic of scrub vegetation, which rarely extends into groves if affected by agricultural activities in the transition zone. Successive plowings seemed to suppress propagules of non-crop species, including shrubs and woody types, thereby reducing the occurrence of scrub vegetation later. Under such a control, the coverage of the scrub vegetation in the sacred compounds in the transition zone was likely equivalent to those in the riverside. A study also indicated that land preparation for agricultural purpose is detrimental to the regeneration of grass and herb species [45].

Extensive coverage of P. juliflora in hinterland compounds appeared to be woodland-like cover. The canopy of Prosopis was more significant than that of the native Acacia species, even in drought conditions with strong sunlight [46], and the evidence corresponded with the results of this study. The antagonistic influence of P. juliflora on the growth of other native species (Table 5) highlighted interesting and important ecological considerations for landscape management of the heritage site. Previous researchers have reported on the invasive capacity of $P$. juliflora that was able to displace and even eliminate native species $[47,48]$. Despite tolerance to the harsh environment of the Dry Zone, native woody and succulent plants might be allelopathically affected by some exudates of $P$. juliflora, which could inhibit the emergence of native plants. The "L-tryptophan" present in the leaves of $P$. juliflora can leach into the soil from leaf litter, thereby considerably inhibiting the growth of native species $[49,50]$. With the grove of $P$. juliflora progressively expanding from the hinterland to the riverside across the transition zone, its influence on the entire landscape of Bagan would presumably alter the ecosystem in the future.

Groundwater availability is also a critical factor for the growth of $P$. juliflora. In the Bagan area, groundwater generally lies between depths of 150 and $250 \mathrm{~m}$; however, the depth lower than $100 \mathrm{~m}$ usually exhibits in the vicinity of the Ayeyarwady River [51]. A dimorphic root system spreading both deep into the soil and laterally near the surface helps P. juliflora to exploit soil water resources [52]. As the root length of $P$. juliflora correlates to the presence of soil water $[53,54]$, water table proximity to 
the soil surface provides favorable conditions for the presence of the species. The sacred compounds within the river and the transition zone are, therefore, vulnerable to the invasion of $P$. juliflora unless there is any implementation of site management.

The sandy loam soil of the Bagan site [51] appears to be influenced by the distribution of P. juliflora roots, even within the shallow soil layer. With local groundwater, the dimorphic root system of the species may also extend horizontally across the subsoil layer, where percolating rainwater may be absorbed. Sandy soil is known to support rainwater leaching, inducing percolation into the layer below. Prosopis root expansion was substantial within $0.5 \mathrm{~m}$ of the soil layer with high sand content [50] and enabled water absorption to a depth of $15 \mathrm{~cm}$ following torrential rain [55]. With roots spreading just beneath the soil surface, a massive grove of $P$. juliflora partially covering monuments may extend roots into the soil below such structures. Rainwater spilling from the structures is also considered to promote the growth of roots, whose penetrative and uplifting effects are threats to the centuries-old monuments.

\subsection{Socio-Cultural Implications of Scrub Vegetation}

Encroachment of scrub vegetation in the sacred compounds indicated associated growth of species, and it shed light on the extensive occurrence of invasive species across the Bagan site. In general, thorny plants with the sparse canopy are significant flora on the land of Bagan [29], and recent research on the spread of similar vegetation across the area around the confluence of Ayeyarwady, Chindwin and $\mathrm{Mu}$ rivers at a few kilometers north to Bagan [43] was consistent with the current study.

Bagan today represents the cultural landscape developed through anthropogenic activities such as settlements, constructions of religious buildings, and agricultural works from the Pre-Bagan period to the current age. Documentations on scattered residential sites around MZ-1, temple constructions in various eras, and agricultural land use in the history supported this statement [16-19,21]. Since the ancient times, settlers in Bagan had cultivated sesamum, sorghum, and millet under the dry-zone climate of Myanmar [23,24]. Such activities would have suppressed the growth of non-crop propagules, which can live for several years to restore successional growth [56]. When fallowed or abandoned, the weedy growth might have induced the occurrence of shrub and woody vegetation in the following years. Enrichment of plant nutrients in the upper soil layer of the cultivated land is a factor that can favor the incidence of annual plants shortly after abandonment, then perennial growths later $[57,58]$. The shrub-hosting patches also create habitat for dispersed seeds of woody species, which later grow into woody vegetation $[59,60]$.

For the related socio-cultural issues in the past, the associated occurrence of scrub vegetation in the sacred compounds highlights the need for landscape management to preserve the monuments as well as the heritage site. The vegetation invasion to the monuments is not typical to Bagan; many abandoned monuments on the world are of similar situations [2,7]. Unlike the monuments in other parts of the world, those in Bagan are hundreds clustering on $228 \mathrm{~km}^{2}$ of land, where settlements and other human-induced features coexist [8]. As mentioned above, the current study endorses the presence of farmlands and agricultural activities in Bagan as a means of preserving the monuments. However, no recommendation goes to the eradication of non-crop vegetation because the presence of such vegetation holds biodiversity in the cultural heritage site. Consistent with the suggestions of Caneva et al. [1], this study also stresses management strategies that can keep the integrity of the cultural landscape on the one hand, and conserving the biodiversity, while considering the possible threats of the invasive species on the other hand. The results of the present study do recommend site management as a priority through multi-disciplinary approaches to safeguard cultural heritage. Although there may be limitations of public interest, financial matters, and other resources, the catalyst of policy implication and institutional supports will sustain the conservation of the World Heritage.

\section{Conclusions}

Scrub vegetation displayed significant interference with the monuments, though shrub-hosting areas and processed land were also remarkable components in the sacred compounds within MZ-1 
of Bagan. Coverage of scrub vegetation quantified $27 \%$ of the sacred compounds, following the occupancy of shrub-hosting areas. Processed land comprising farmland, active monastic residences, and accessways occupied $25 \%$, whereas the proportion of land taken up by the monuments was less than $10 \%$. The zonal characteristics of scrub vegetation indicated the encroachment of invasive P. juliflora into the zones close to the Ayeyarwady River. While native scrub-type plants occurred in associated growth, the invasion of $P$. juliflora suppressed the growth of native scrub vegetation.

The presence of farmland in the sacred compounds was a good indication of controlling the invasion of scrub vegetation, which may be hosted by shrub patches in the earlier stage. As an alternative, abandonment of the cultivated land can facilitate the growth of weedy species, including shrubs, and later woody plants. Retaining agricultural activities in Bagan, therefore, is a tactical move to serve the integrity of the entire landscape. Unless otherwise, the extensive occurrence of scrub vegetation in the proximity of and on the monuments would accelerate the deterioration of the cultural heritage. Under such conditions, unmanaged vegetation growth would degrade the landscape of Bagan with deteriorated monuments in the future. Although no suggestion raised eliminating all the non-crop vegetation, the results of the current study do recommend formulating and implementing site management through multi-disciplinary efforts by various stakeholders. As for sustainability, the contribution of local management practices to the integrity of the cultural landscape is of utmost importance. The collaborative actions of stakeholders from various disciplines with support from regional and national governments will strengthen the long-term movement. Finally, further examinations based on the current results are helpful to integrate into safeguarding the World Cultural Heritage in Bagan due to some administrative restrictions on the coverage of on-ground research in the study reported here.

Author Contributions: Conceptualization, methodology, investigation, formal analysis, writing original draft and manuscript by M.Z.N.A.; Supervision, review and editing by S.S.

Funding: This research was funded by the Japan International Cooperation Agency (JICA) under the Long-term Training Program for Academic Staff at Yezin Agricultural University for Postgraduate Degrees (Ph.D.) in Japan. The APC was funded by Kyoto University.

Acknowledgments: The authors acknowledge the Technical Cooperation Project of Yezin Agricultural University and the Japan International Cooperation Agency (YAU-JICA TCP) for the support provided in field operations. Thanks are also due to the Department of Civil Aviation (Ministry of Transport and Communication) and the Department of Archaeology and National Museum (Ministry of Religious Affairs and Culture) of the Republic of the Union of Myanmar for their collaboration and guidance with aerial photography at the research site.

Conflicts of Interest: The authors have no conflicts of interest to declare.

\section{References}

1. Caneva, G.; Benelli, F.; Bartoli, F.; Cicinelli, E. Safeguarding natural and cultural heritage on Etruscan tombs (La Banditaccia, Cerveteri, Italy). Rend. Lincei. Sci. Fis. Nat. 2018, 29, 891-907. [CrossRef]

2. Caneva, G.; Bartoli, F.; Ceschin, S.; Salvadori, O.; Futagami, Y.; Salvati, L. Exploring ecological relationships in the biodeterioration patterns of Angkor temples (Cambodia) along a forest canopy gradient. J. Cult. Herit. 2015, 16, 728-735. [CrossRef]

3. Steinbauer, M.J.; Gohlke, A.; Mahler, C.; Schmiedinger, A.; Beierkuhnlein, C. Quantification of wall surface heterogeneity and its influence on species diversity at medieval castles-implications for the environmentally friendly preservation of cultural heritage. J. Cult. Herit. 2013, 14, 219-228. [CrossRef]

4. Motti, R.; Stinca, A. Analysis of the biodeteriogenic vascular flora at the Royal Palace of Portici in southern Italy. Int. Biodeterior. Biodegrad. 2011, 65, 1256-1265. [CrossRef]

5. Caneva, G.; Galotta, G.; Cancellieri, L.; Savo, V. Tree roots and damages in the Jewish catacombs of Villa Torlonia (Roma). J. Cult. Herit. 2009, 10, 53-62. [CrossRef]

6. Mishra, A.K.; Jain, K.K.; Garg, K.L. Role of higher plants in the deterioration of historic buildings. Sci. Total Environ. 1995, 167, 375-392. [CrossRef]

7. Caneva, G.; Pacini, A.; Grapow, L.C.; Ceschin, S. The Colosseum's use and state of abandonment as analysed through its flora. Int. Biodeterior. Biodegrad. 2003, 51, 211-219. [CrossRef] 
8. Aung, M.Z.N.; Shibata, S. Contemporary landscape structure within Monumental Zone-1 at the Bagan Cultural Heritage Site, Myanmar. Heritage 2019, 2, 1748-1761. [CrossRef]

9. Forest Department. Forest Reference Level (FL) of Myanmar; Ministry of Natural Resources and Environmental Conservation: Nay Pyi Taw, Myanmar, 2018. Available online: https://redd.unfccc.int/files/2018_frel_ submission_myanmar.pdf (accessed on 27 May 2019).

10. Food and Agricultural Organization. The State of the World's Forest Genetic Resources, Country Report: Myanmar; FAO: Rome, Italy, 2010; Available online: http://www.fao.org/3/i3825e/i3825e46.pdf (accessed on 27 May 2019).

11. Kress, W.J.; DeFilipps, R.A.; Farr, E.; Kyi, Y.Y. A brief review of the geology, climate and vegetation of Myanmar. In A Checklist of the Trees, Shrubs, Herbs, and Climbers of Myanmar; Department of Systematic Biology-Botany, National Museum of Natural History, Smithsonian Institution: Washington, DC, USA, 2003; Volume 45, pp. 19-31.

12. Briggs, J.M.; Spielmann, K.A.; Schaafsma, H.; Kintigh, K.W.; Kruse, M.; Morehouse, K.; Schollmeyer, K. Why ecology needs archaeologists and archaeology needs ecologists. Front. Ecol. Environ. 2006, 4, 180-188. [CrossRef]

13. Dehnen-Schmutz, K. Alien species reflecting history: Medieval castles in Germany. Divers. Distrib. 2004, 10, 147-151. [CrossRef]

14. Roy, N.; Bhiry, N.; Woollett, J.; Fréchette, B. Vegetation history since the mid-Holocene in northeastern Iceland. Ecoscience 2018, 25, 109-123. [CrossRef]

15. Wacnik, A.; Tylmann, W.; Bonk, A.; Goslar, T.; Enters, D.; Meyer-Jacob, C.; Grosjean, M. Determining the responses of vegetation to natural processes and human impacts in north-eastern Poland during the last millennium: combined pollen, geochemical and historical data. Veg. Hist. Archaeobot. 2016, 25, 479-498. [CrossRef]

16. Hudson, B.; Lwin, N.; Maung, W. The origins of Bagan: New dates and old inhabitants. Asian Perspect. 2001, 40, 48-74. [CrossRef]

17. Hudson, B. The Origins Bagan. The archaeological landscape of Upper Burma to A.D. 1300. Ph.D. Thesis, The University of Sydney, New South Wales, Australia, 2004; pp. 188-219.

18. Hudson, B. Restoration and reconstruction of monuments at Bagan (Pagan), Myanmar (Burma), 1995-2008. World Archae. 2008, 40, 553-571. [CrossRef]

19. Han, N. A Retrospective and Prospective Review on the Conservation of Ancient Monuments in Pagan. Cultural Heritage in Asia (4): Study on Pagan, Mandalay and Pagan, Myanmar, 1-6 August 1988; Institute of Asian Cultures, Sophia University: Tokyo, Japan, 1989; pp. 91-99.

20. Hla, T. Anantasura's Inscriptions: Why among Others? Bagan Metropolis, Yangon, Myanmar, 9-15 July 2017; SOAPS University of London: London, UK; Available online: https://www.soas.ac.uk/saaap/news/file124888.pdf (accessed on 6 April 2019).

21. Trager, F.N.; Koenig, W.J. Central Burma. In Burmese Sit-Tans 1764-1826: Records of Rural Life and Administration; The University of Arizona Press: Tucson, AZ, USA, 1979; pp. 190-356.

22. Aung-Twin, M. The institutional context: Organization of human and material resources. In Pagan: The Origins of Modern Burma; University of Hawaii Press: Honolulu, HI, USA, 1985; pp. 69-165.

23. Tun, T. Agriculture in Myanmar, A. D. 1000-1300. In Some Observations on History and Culture of Early Myanmar; Myanmar Historical Commission, Ministry of Education, Union of Myanmar: Yangon, Myanmar, 2004; pp. 22-29.

24. Luce, G.H. Economic life of the early Burman. J. Burma Res. Soc. 1940, 30, 283-335.

25. Koller, A. Architectural design at Bagan and Angkor: A comparison. J. R. Asiat. Soc. 2017, $27,93-141$. [CrossRef]

26. Pichard, P. Inventory of Monuments at Pagan; Kiscadale EFEO UNESCO: Paris, France, 1992-1995; Volumes 1-6.

27. Tun, T. Religious buildings of Burma A.D. 1000-1300. J. Burma Res. Soc. 1959, 42, 71-80.

28. Tun, T. Religion in Burma, A. D. 1000-1300. J. Burma Res. Soc. 1959, 42, 47-69.

29. Luce, G.H. Rise of Pagan. In Old Burma-Early Pagan; J. J. Augustin Publisher: New York, NY, USA, 1969; Volume 1, pp. 4-11.

30. World Heritage Committee. Convention Concerning the Protection of the World Cultural and Natural Heritage. Thirty Second Session, Quebec, Canada, 2-10 July 2008; UNESCO: Paris, France, 2008; Available online: http://whc.unesco.org/archive/2008/whc08-32com-9e.pdf (accessed on 8 October 2019). 
31. Department of Archaeology and National Museum. Proposed World Heritage List Bagan: Cultural Heritage Sites in Myanmar; Ministry of Religious Affairs and Culture, The Republic of the Union of Myanmar: Nay Pyi Taw, Myanmar, 2018.

32. Department of Population. The 2014 Myanmar Population and Housing Census, Mandalay Region, Nyaung-U District, Nyaung-U Township; Ministry of Labour, Immigration and Population, The Republic of the Union of Myanmar: Nay Pyi Taw, Myanmar, 2017. Available online: www.dop.gov.mm/sitesdop.gov.mm/files/ publication_docs/naung_u.pdf (accessed on 1 April 2019).

33. Hudson, B. The King of Free Rabbit Island: A G.I.S.-based archaeological approach to Myanmar's medieval capital, Bagan. In Proceedings of the Myanmar Two-millennial Conference, Yangon, Myanmar, 15-17 December 1999; Universities Historical Research Centre: Yangon, Myanmar, 2000; pp. 10-19.

34. Myanmar Information Management Unit (MIMU). Myanmar State/Region (with Sub-Regions), District, Township Boundary Lines. 2019. Available online: geonode.themimu.info/layers/?limit=100\&offset=0 (accessed on 11 June 2019).

35. United States Geological Survey (USGS). Available online: https://earthexplorer.usgs.gov/ (accessed on 7 October 2019).

36. Natural Earth. Available online: https://www.naturalearthdata.com/downloads/10m-raster-data/10mnatural-earth-1/ (accessed on 7 October 2019).

37. Pichard, P. Inventory of Monuments at Pagan; Kiscadale EFEO UNESCO: Paris, France, 1992; Volume 1 (Monuments 1-255), pp. 1-41.

38. Csecserits, A.; Botta-Dukát, Z.; Kröel-Dulay, G.; Lhotsky, B.; Ónodi, G.; Rédei, T.; Szitár, K.; Halassy, M. Tree plantations are hot-spots of plant invasion in a landscape with heterogeneous land-use. Agric. Ecosyst. Environ. 2016, 226, 88-98. [CrossRef]

39. Mosher, E.S.; Silander, J.A., Jr.; Latimer, A.M. The role of land-use history in major invasions by woody plant species in the northeastern North American landscape. Biol. Invasions 2009, 11, 2317-2318. [CrossRef]

40. Aung-Twin, M. The effects of beliefs and institutions on events. In Pagan: The Origins of Modern Burma; University of Hawaii Press: Honolulu, HI, USA, 1985; pp. 167-198.

41. Aung-Thwin, M.; Aung-Thwin, M. Pagan: The golden age of Myanmar. In A History of Myanmar Since Ancient Times, Traditions and Transformations; Reaktion Books Ltd.: London, UK, 2012; pp. 77-106.

42. Davis, J.H. Classification of types of forests and other woody vegetation. In The Forest of Burma; University of Florida: Gainesville, FL, USA, 1960; pp. 2-4.

43. Oo, W.P.; Koike, F. Dry forest community types and their predicted distribution based on a habitat model for the central dry zone of Myanmar. For. Ecol. Manag. 2015, 358, 108-121. [CrossRef]

44. Aung, T.; Koike, F. Identification of invasion status using a habitat invasibility assessment model: The case of Prosopis species in the dry zone of Myanmar. J. Arid Environ. 2015, 120, 87-95. [CrossRef]

45. Deak, B.; Tothmeresz, B.; Valko, O.; Sudnik-Wojcikowska, B.; Moysiyenko, I.I.; Bragina, T.M.; Apostolova, I.; Dembicz, I.; Bykov, N.I.; Torok, P. Cultural monuments and nature conservation: A review of the role of kurgans in the conservation and restoration of steppe vegetation. Biodivers. Conserv. 2016, 25, 2473-2490. [CrossRef]

46. Abbas, A.M.; Rubio-Casal, A.E.; De Cires, A.; Grewell, B.J.; Castillo, J.M. Differential tolerance of native and invasive tree seedlings from arid African deserts to drought and shade. S. Afr. J. Bot. 2019, 123, 228-240. [CrossRef]

47. Mukherjee, A.; Velankar, A.D.; Kumara, H.N. Invasive Prosopis juliflora replacing the native floral community over three decades: A case study of a World Heritage Site, Keoladeo National Park, India. Biodivers. Conserv. 2017, 26, 2839-2856. [CrossRef]

48. Shackleton, R.T.; LeMaitre, D.C.; VanWilgen, B.W.; Richardson, D.M. The impact of invasive alien Prosopis species (mesquite) on native plants in different environments in South Africa. S. Afr. J. Bot. 2015, 97, $25-31$. [CrossRef]

49. Nakano, H.; Nakajima, E.; Fujii, Y.; Yamada, K.; Shigemori, H.; Hasegawa, K. Leaching of the allelopathic substance L-tryptophan from the foliage of mesquite (Prosopis juliflora (Sw.) DC.) plants by water spraying. Plant Growth Regul. 2003, 40, 49-52. [CrossRef]

50. Muturi, G.M.; Poorter, L.; Bala, P.; Mohren, G.M.J. Unleached Prosopis litter inhibits germination but leached stimulates seedling growth of dry woodland species. J. Arid Environ. 2017, 138, 44-50. [CrossRef] 
51. Drury, L.W. Hydrology of the Dry Zone-Central Myanmar; The Australian Water Partnership: Canberra, Australia, 2017; pp. 13-16. Available online: http://themimu.info/sites/themimu.info/files/documents/Report_ Hydrogeology_of_the_Dry_Zone-Central_Myanmar_2017_low-res.pdf (accessed on 1 August 2018).

52. Guevara, A.; Pancotto, V.; Mastrantonio, L.; Giordano, C.V. Fine roots of Prosopis flexuosa trees in the field. Plant and soil variables that control their growth and depth distribution. Plant Ecol. 2018, 219, 1399-1412. [CrossRef]

53. Zhou, Y.; Watts, S.E.; Boutton, T.W.; Archer, S.R. Root density distribution and biomass allocation of co-occurring woody plants on contrasting soils in a subtropical savanna parkland. Plant Soil 2019, 43, 263-279. [CrossRef]

54. Zhou, Y.; Boutton, T.W.; Wu, X.B.; Wright, C.L.; Dion, A.L. Rooting strategies in a subtropical savanna: A landscape-scale three-dimensional assessment. Oecologia 2018, 186, 1127-1135. [CrossRef] [PubMed]

55. Saito, T.; Yasuda, H.; Sakurai, M.; Acharya, K.; Sueki, S.; Inosako, K.; Yoda, K.; Fujimaki, H.; Abd Elbasit, M.A.M.; Eldoma, A.M.; et al. Monitoring of stem water content of native and invasive trees in arid environments using GS3 soil moisture sensors. Vadose Zone J. 2016, 15, 1-9. [CrossRef]

56. Cai, W.; Guan, T.; Li, H.; Lai, L.; Zhang, X.; Zhou, J.; Jiang, L.; Zheng, Y. Vegetation succession of abandoned croplands in Ruanliang and Yingliang in the Ordos Plateau. Acta Ecol. Sin. 2018, 38, 21-28. [CrossRef]

57. Piche, N.; Kelting, D.L. Recovery of soil productivity with forest succession on abandoned agricultural land. Restor. Ecol. 2015, 23, 645-654. [CrossRef]

58. Kumar, S.; Mathur, M. Impact of invasion by Prosopis juliflora on plant communities in arid grazing lands. Trop. Ecol. 2014, 55, 33-46.

59. Bueno, A.; Llambi, L.D. Facilitation and edge effects influence vegetation regeneration in old-fields at the tropical Andean forest line. Appl. Veg. Sci. 2015, 18, 613-623. [CrossRef]

60. Holl, K.D. Effect of shrub on tree seedling establishment in an abandoned tropical pasture. J. Ecol. 2002, 90, 179-187. [CrossRef]

(C) 2019 by the authors. Licensee MDPI, Basel, Switzerland. This article is an open access article distributed under the terms and conditions of the Creative Commons Attribution (CC BY) license (http://creativecommons.org/licenses/by/4.0/). 